\title{
In Vivo Exposure to Bisphenol-A Altered the Reproductive Functionality in Male Coturnix Coturnix Japonica
}

SUTHAN PERMUAL

Central Avian Research Institute

GAUTHAM KOLLURI ( $D$ Gautham.Kolluri@icar.gov.in )

Central Avian Research Institute

JAG MOHAN

Central Avian Research Institute

RAM SINGH

Salim Ali Center for Ornithology and Natural History

JAGBIR TYAGI

Central Avian Research Institute

\section{Research Article}

Keywords: Bisphenol-A, quails, sperm quality, fertility

Posted Date: December 21st, 2020

DOI: https://doi.org/10.21203/rs.3.rs-124102/v1

License: (a) (i) This work is licensed under a Creative Commons Attribution 4.0 International License.

Read Full License 


\section{Abstract}

Bisphenol-A, is one of the most characterized endocrine disruptors on the reproductive functions in humans and animals. We have previously reported in vitro and in vivo effects of bisphenol-A on functional role of sperm in chicken. Here, the effects of 1 and $5 \mathrm{mg} / \mathrm{kg}$ bisphenol-A daily administered by gavage for 3 wk to adult male Japanese quails on reproductive functionality was investigated. Cloacal index and foam frequency were greatly reduced at high dose. Sperm quality attributes were affected at both doses. Sperm quality attributes were affected at both doses. Alkaline phosphatase showed most significant reduction among seminal enzymes. Dose dependent response $(P<0.01)$ of bisphenol-A was noticed with modulating testosterone concentrations at low and high doses. Disturbances regarding fertility and hatchability traits were prominent in high and low dose groups. The current study confirms the compromising actions of bisphenol-A on reproductive success in male Japanese quails at lower doses that are considered to be safe (50 mg/kg BW/d) under in vivo exposure module. These results indicate higher sensitivity of quails to bisphenol-A toxicity and explores the possibility of using quail subjects as an accurate toxic indicators.

\section{Introduction}

Bisphenol-A (BPA), an estrogenic mimicker has attracted research interest ever since its wide spread use in late 1940's in consumer plastic products ${ }^{1,2}$ owing to its undesirable effects on human and animal health. The interactive ability of BPA is wider and it is reported to bind to estrogens ${ }^{3,4}$ androgens $s^{5,6}$, thyroid hormones ${ }^{7}$ and immune mediated receptors ${ }^{8,9,10}$, besides affecting various physiological systems. Previous studies reported the potential damaging role of BPA in humans, animals and birds $3,11,12,13$. In males, compromising effects of BPA involves damage to prostate gland, sperm DNA and impairment of semen production. Animal studies have reported the negative effects of BPA on male reproductive health including sperm production and quality, steroidogenesis, male urinary tract development, and sexual dysfunction ${ }^{14}$. Though reprotoxic effects of BPA have been well characterized in mammalian species using rodent models, very limited reports could be fetched with regard to avians ${ }^{15,16}$. We have recently reported negative effects of BPA on sperm motility, livability, abnormality and plasma membrane integrity, mitochondrial membrane potential in chicken under in vitro ${ }^{17}$ and in vivo ${ }^{18}$ conditions.

Avian studies aiming at reproductive toxicity of BPA involved wide range of doses and duration which are unrelated to environmentally relevant concentrations ${ }^{16,19,20,21}$. At a concentration of $62 \mu \mathrm{M} / \mathrm{L}, \mathrm{BPA}$ has compromised the viability of chicken embryonic hepatocytes ${ }^{22}$. Two different studies in quails observed no effects ${ }^{23}$ and oviductal abnormalities when administered with BPA at $200 \mu \mathrm{g}$ per egg. Further it also caused feminization of left testes in male chickens ${ }^{15}$. Chickens when exposed for 23 wk with $2 \mu \mathrm{g} / \mathrm{kg}$ with $2 \mathrm{~d}$ interval altered male phenotypes viz., comb, wattles, testes apart from delayed growth. In response to potential higher doses $(200 \times 106 \mu \mathrm{g})$ of BPA for $14 \mathrm{wk}$ period has resulted in reductions of comb and testes $^{16}$. 
BPA exposure is ubiquitous in humans and birds, with ingestion being the major exposure route ${ }^{24}$. BPA is not covalent in nature and therefore may unbind from products via leaching into the environment ${ }^{18}$. In poultry, use of legumes, soy proteins, plastic feeders and water troughs are most common routes for BPA exposure. Birds represent an excellent bio-indicator for monitoring the toxicological residues in biological systems. Among the domestic aves, Japanese quail offers an excellent model for studying possible mechanisms of endocrine disruptors due to its smaller size, shorter generation interval, ubiquitous existence and intimacy with living environment. In addition, the male reproductive function has a unique "androgen dependent cloacal gland", which can be used as an external marker for reprotoxic alterations ${ }^{25,26}$. Studies to date have shown that the male Japanese quail is exquisitely sensitive to the effects of exogenous estrogen $23,27,28$. In-ovo administration of BPA in chicken and quail and suggested that early embryonic period is more sensitive to estrogenic endocrine disrupting compounds ${ }^{15,28}$. It produced oviduct abnormality in female quail and delayed the growth of comb, wattle, and testis in male chicken ${ }^{16}$. Nevertheless, studies on effect of BPA on reproductive function in adult quail are lacking. Accumulated research evidence, suggests the existence of degree of variation in terms of species sensitivity to BPA. Considering aforementioned, the current study was designed with an intention to elucidate the biological effects of variable BPA exposure levels in male Japanese quails by analyzing the sperm quality and other biochemical estimates that reflect the male reproductive functionality. This may allow us to address the research question whether quails can be used as accurate biological indicators for BPA?

\section{Results And Discussion}

The established lowest-observed-adverse-affect-level (LOAEL) or No-observed-adverse-affect-level (NOAEL) for BPA by US Environmental Protection Agency (EPA) and European Union Risk Assessment Report (EURAR) ${ }^{29}$ is $50 \mathrm{mg} / \mathrm{kg} \mathrm{BW/d}$. For BPA induced reproductive and developmental toxicity, same dose has been set as NOAEL ${ }^{30,31}$. These reference doses were based on the rodent studies with chronic exposure to $\mathrm{BPA}^{32}$. Accurate dose calculation in avians based on the previously reported animal or human studies is difficult; due to absence of absolute constants pertaining to human-animal equivalent dose conversion. To study the BPA induced reproductive toxicity in male quails at lower than doses considered to be safe, the reference dose $(50 \mathrm{mg} / \mathrm{kg} \mathrm{BW} / \mathrm{d}$ ) was divided by a factor of ten and fifty to obtain low $(1 \mathrm{mg} / \mathrm{kg} \mathrm{BW}$ ) and higher $(5 \mathrm{mg} / \mathrm{kg} \mathrm{BW}$ ) level respectively. The doses used in the current study were based on previous reports in chicken ${ }^{18}$ and rodents ${ }^{33}$.

Data generated from linear regression analysis (Table 1) indicated a positive relationship of varied BPA doses with sperm abnormality, ALT and MBRT, while negative relationship with other parameters. Except, MBRT and LDH the relationship was found to be significantly $(P<0.01)$ affected. 
Table 1

Linear regression analysis of the various study parameters used in the study

\begin{tabular}{|c|c|c|c|c|}
\hline & $\mathrm{R}^{2}$ & Equation & Significance & df \\
\hline Body weight & 0.00 & $Y=-0.0003891 * X+192.8$ & 0.74 & 115 \\
\hline Testicular weight & 0.41 & $Y=-0.0001727 * X+2.691$ & 0.00 & 22 \\
\hline Relative testes weight & 0.49 & $Y=-0.0001045^{*} X+1.501$ & 0.00 & 22 \\
\hline Percent change in cloacal gland index & 0.09 & $Y=-0.001812^{*} X+9.4$ & 0.01 & 76 \\
\hline Foam frequency & 0.07 & $Y=-0.0003727 * X+6.569$ & 0.00 & 291 \\
\hline Fertility & 0.88 & $Y=-0.005534 * X+71.98$ & 0.00 & 10 \\
\hline Hatchability on TES & 0.82 & $Y=-0.004896 * X+60.2$ & 0.00 & 10 \\
\hline Hatchability on FES & 0.77 & $Y=0.0002152 * X+82.31$ & 0.01 & 10 \\
\hline Testosterone & 0.37 & $Y=-0.000404 * X+4.085$ & 0.00 & 70 \\
\hline ACP & Nil & - & - & - \\
\hline ALP & 0.50 & $Y=-0.0005184 * X+3.132$ & 0.00 & 22 \\
\hline AST & 0.17 & $Y=0.1699 * X+2729$ & 0.04 & 22 \\
\hline LDH & 0.03 & $Y=-0.0004196 * X+34.89$ & 0.44 & 22 \\
\hline Semen volume & 0.12 & $Y=-0.0004008 * X+7.174$ & 0.00 & 215 \\
\hline Sperm motility & 0.20 & $Y=-0.001316 * X+77.59$ & 0.02 & 26 \\
\hline Sperm concentration & 0.35 & $Y=-0.0001236 * X+2.234$ & 0.00 & 30 \\
\hline Sperm livability & 0.36 & $Y=-0.1699 * X+2729$ & 0.00 & 30 \\
\hline Sperm abnormality & 0.36 & $Y=0.001575 * X+7.88$ & 0.00 & 30 \\
\hline Semen $\mathrm{pH}$ & 0.31 & $Y=-0.11 * X+7.35$ & 0.01 & 22 \\
\hline MBRT & 0.36 & $Y=25.85^{\star} X+18.25$ & 0.00 & 30 \\
\hline
\end{tabular}

\section{Not body weight but testicular weights strongly affected by BPA}

Mean body weight of quails exposed to BPA did not show any biological variation throughout the study period (Table 2). Oral administration of BPA witnessed drastic reductions in combined testicular weights testes in absolute and relative terms (Table 3$)$ in a significant $(P<0.01)$ and dose dependent manner $\left(r^{2}=\right.$ 0.41) (Table 3) with in-significant change in untreated (T1) and vehicle treated groups (T2). The maximum reduction in absolute and relative weights was noted up to 34.79 and $36.61 \%$, respectively, in the high dose BPA-treated group of animals. BPA altered testicular weights were reported in chicken ${ }^{22}$ and rats ${ }^{34,35}$. 
Lowered testicular weights decrease in BPA administered groups (T3 and T4) in contrast with respective controls affirms the testicular toxicity production ${ }^{36}$ and may be due to proteomic and cellular alterations induced in seminiferous tubules and leydig cells of testes ${ }^{37,38}$.

Table 2

Effect of BPA on body weights (g) of Japanese quail (Mean \pm S.E.M., $n=15$ )

\begin{tabular}{|lllll|}
\hline & $\mathbf{8}$ weeks & $\mathbf{9}$ weeks & 10 weeks & Mean Duration \\
\hline T1 (Buffer Control) & $189.65 \pm 9.78$ & $188.30 \pm 11.03$ & $183.15 \pm 7.99$ & $187.03 \pm 4.62$ \\
\hline T2 (Sham Control) & $186.85 \pm 5.95$ & $194.05 \pm 4.93$ & $195.75 \pm 8.00$ & $192.22 \pm 4.62$ \\
\hline T3 (Low dose BPA) & $198.85 \pm 8.58$ & $202.5 \pm 8.74$ & $204.97 \pm 9.20$ & $202.11 \pm 4.62$ \\
\hline T4 (High dose BPA) & $194.20 \pm 6.62$ & $193.100 \pm 7.04$ & $187.34 \pm 9.78$ & $191.55 \pm 4.94$ \\
\hline Treatment Mean & $192.39 \pm 4.00$ & $194.49 \pm 4.00$ & $192.80 \pm 4.21$ & \\
\hline Significance & & & & \\
\hline Treatment & $0.93^{\text {NS }}$ & & & \\
\hline Duration & 0.14 NS & & & \\
\hline Treatment $\times$ Duration & $0.96^{\text {NS }}$ & & & \\
\hline
\end{tabular}

Table 3

Testicular weights $(\mathrm{g})$ of Japanese quails as influenced by BPA administration (Mean \pm S.E, $n=$ 8)

\begin{tabular}{|lllll|}
\hline Treatment groups & Left & Right & Absolute Mean Weight & Relative Weight \\
\hline T1 (Buffer Control) & $3.14 \pm 0.08$ & $2.77 \pm 0.17$ & $2.96^{\mathrm{b}} \pm 0.13$ & $1.61^{\mathrm{b}} \pm 0.06$ \\
\hline T2 (Sham Control) & $3.01 \pm 0.26$ & $2.47 \pm 0.18$ & $2.74^{\mathrm{b}} \pm 0.22$ & $1.55^{\mathrm{b}} \pm 0.11$ \\
\hline T3 (Low dose BPA) & $2.42 \pm 0.17$ & $1.71 \pm 0.11$ & $2.07^{\mathrm{a}} \pm 0.14$ & $1.16^{\mathrm{a}} \pm 0.04$ \\
\hline T4 (High dose BPA) & $2.22 \pm 0.26$ & $1.65 \pm 0.08$ & $1.93^{\mathrm{a}} \pm 0.17$ & $1.02^{\mathrm{a}} \pm 0.06$ \\
\hline Significance & & & $0.000^{\star *}$ & $0.000^{\star \star}$ \\
\hline abc Means bearing different superscript within columns differs significantly. & \\
\hline
\end{tabular}

\section{Exposure to BPA altered cloacal gland index and frequency of foam production in quails}

From various researchers, it is understood that BPA has multifaceted targets on spermatozoa rendering it ineligible to deploy its functional duties in female reproductive tract. Recent evidence suggests that 
phosphorylation of fertility-related proteins critically gets interfered by this chemical concentrations ${ }^{38}$. Being smaller in body size, quails are inferred to have higher metabolic activity than other domestic poultry species ${ }^{39}$. The reproductive system of male Japanese quail is unique among all the avian species because of the presence of androgen dependent cloacal gland ${ }^{40}$. In sexually active male birds, the cloacal gland is enlarged and there is high degree of correlation between gland size and testicular mass which indicates its role in predicting the fertilizing potential in this species ${ }^{41}$. The cloacal gland secretes meringue-like white foam constantly during copulation and defecation time ${ }^{42}$. Results pertaining to percent mean change in cloacal gland index and foam frequency were presented in Tables 4 and 5 respectively. Exposure to BPA reduced cloacal gland indices with high dose group witnessing a percent change of 0.59 than its control counterpart (11.24). Over a period of time, percent change deteriorated $(\mathrm{P}<$ $0.05)$ in BPA groups. The current study witnessed a significant $(P<0.01)$ variation in number of times the foam being produced by quails with respect to BPA administration. Foam frequency was typically reduced at high dose (4.85) followed by low dose (5.75) and control groups (6.65). Interaction of BPA and period of exposure revealed a significant effect of foam frequency. The alteration in cloacal gland area in BPA treated groups over period of time clearly explains the lowered foam discharge frequency in this study (Table 5). Our experiments on DES in quails ${ }^{43}$ also revealed a compromised cloacal gland size. Withstanding to the fact that androgens modulate cloacal gland, the BPA induced lowered testosterone concentration (Fig. 1) may explain the shrinkage of cloacal gland size in the study groups.

Table 4

Effect of BPA on percent change in cloacal gland index of Japanese quails at different time points (Mean $\pm S . E, n=15)$

\begin{tabular}{|llllll|}
\hline $\begin{array}{l}\text { Duration } \\
\text { (weeks) }\end{array}$ & $\begin{array}{l}\text { T1 (Buffer } \\
\text { Control) }\end{array}$ & $\begin{array}{l}\text { T2 (Sham } \\
\text { Control) }\end{array}$ & $\begin{array}{l}\text { T3 (Low } \\
\text { dose BPA) }\end{array}$ & $\begin{array}{l}\text { T4 (High } \\
\text { dose BPA) }\end{array}$ & $\begin{array}{c}\text { Duration } \\
\text { Mean }\end{array}$ \\
\hline 9 weeks & $17.22 \pm 2.79$ & $14.26 \pm 3.48$ & $12.31 \pm 1.71$ & $12.46 \pm 2.97$ & $14.06^{\mathrm{b}} \pm$ \\
\hline 10 weeks & $5.28 \pm 2.4$ & $2.2 \pm 2.56$ & $3.42 \pm 0.92$ & $11.28 \pm 2.65$ & $-0.094^{\mathrm{a}} \pm$ \\
\hline $\begin{array}{l}\text { Treatment } \\
\text { mean }\end{array}$ & $11.26 \pm 1.77$ & $8.23 \pm 1.77$ & $7.87 \pm 1.77$ & $0.59 \pm 1.87$ & 1.27 \\
\hline $\begin{array}{l}\text { Significance } \\
\text { Treatment }\end{array}$ & $0.21^{\mathrm{NS}}$ & & & \\
\hline Duration & $0.00^{\star *}$ & & & \\
\hline $\begin{array}{l}\text { Treatment } \times \\
\text { Duration }\end{array}$ & $0.28^{\mathrm{NS}}$ & & & \\
\hline abcMeans bearing different superscript within columns differs significantly $(\mathrm{P}<0.05)$ & \\
\hline
\end{tabular}


Table 5

Foam frequency at different time points in Japanese quails as influenced by BPA administration (Mean \pm S.E, $n=15)$

\begin{tabular}{|c|c|c|c|c|c|}
\hline $\begin{array}{l}\text { Duration } \\
\text { (days) }\end{array}$ & $\begin{array}{l}\text { T1 (Buffer } \\
\text { Control) }\end{array}$ & $\begin{array}{l}\text { T2 (Sham } \\
\text { Control) }\end{array}$ & $\begin{array}{l}\text { T3 (Low } \\
\text { dose BPA) }\end{array}$ & $\begin{array}{l}\text { T4 (High } \\
\text { dose BPA) }\end{array}$ & $\begin{array}{l}\text { Duration } \\
\text { Mean }\end{array}$ \\
\hline D1 & $\begin{array}{l}6.13^{\mathrm{abcd}} \pm \\
0.99\end{array}$ & $\begin{array}{l}5.67^{\mathrm{abcd}} \pm \\
0.88\end{array}$ & $\begin{array}{l}6.00^{\mathrm{abcd}} \pm \\
1.12\end{array}$ & $7.38^{\mathrm{bcd}} \pm 0.98$ & $6.29 \mathrm{XYZ} \pm 0.44$ \\
\hline D3 & $\begin{array}{l}4.60^{\mathrm{abcd} \pm} \\
0.96\end{array}$ & $\begin{array}{l}6.56^{\mathrm{abcd}} \pm \\
0.96\end{array}$ & $\begin{array}{l}6.14^{\mathrm{abcd} \pm} \\
0.74\end{array}$ & $\begin{array}{l}5.30^{\mathrm{abcd}} \pm \\
0.86\end{array}$ & $5.65 \mathrm{XYZ} \pm 0.43$ \\
\hline D5 & $\begin{array}{l}6.00^{\mathrm{abcd}} \pm \\
1.07^{-}\end{array}$ & $\begin{array}{l}5.11^{\mathrm{abcd}} \pm \\
0.73\end{array}$ & $\begin{array}{l}6.14^{\mathrm{abcd}} \pm \\
0.74\end{array}$ & $\begin{array}{l}6.00^{\mathrm{abcd}} \pm \\
0.80\end{array}$ & $5.81^{X Y Z} \pm 0.44$ \\
\hline D7 & $\begin{array}{l}7.60^{\mathrm{bcd}} \pm \\
0.56\end{array}$ & $8.10^{c d} \pm 0.69$ & $\begin{array}{l}6.30^{\mathrm{abcd}} \pm \\
1.10\end{array}$ & $\begin{array}{l}4.40^{\mathrm{abcd}} \pm \\
0.65\end{array}$ & $6.60 \mathrm{YZ} \pm 0.40$ \\
\hline D9 & $\begin{array}{l}7.44^{\mathrm{bcd}} \pm \\
0.99\end{array}$ & $\begin{array}{l}7.00^{\mathrm{abcd}} \pm \\
1.05\end{array}$ & $8.50^{d} \pm 1.18$ & $\begin{array}{l}4.78^{\mathrm{abcd}} \pm \\
0.81\end{array}$ & $6.78^{z} \pm 0.42$ \\
\hline D11 & $\begin{array}{l}7.90^{\mathrm{bcd}} \pm \\
0.82\end{array}$ & $\begin{array}{l}7.30^{\mathrm{abcd}} \pm \\
0.90\end{array}$ & $\begin{array}{l}6.60^{\mathrm{abcd}} \pm \\
0.88\end{array}$ & $3.90^{a b c} \pm 0.74$ & $6.43^{\mathrm{YZ}} \pm 0.40$ \\
\hline D13 & $\begin{array}{l}7.20^{\mathrm{abcd}} \pm \\
0.71\end{array}$ & $\begin{array}{l}6.40^{\mathrm{abcd}} \pm \\
0.48\end{array}$ & $\begin{array}{l}4.22^{\mathrm{abcd} \pm} \\
0.70\end{array}$ & $3.38^{a b} \pm 0.60$ & $5.23^{\Upsilon}- \pm 0.42$ \\
\hline D15 & $\begin{array}{l}6.67^{\mathrm{abcd}} \pm \\
0.82\end{array}$ & $\begin{array}{l}7.10^{\mathrm{abcd}} \pm \\
0.80\end{array}$ & $2.78^{a} \pm 0.46$ & $3.70^{a b c} \pm 0.54$ & $5.07^{x} \pm 0.42$ \\
\hline $\begin{array}{l}\text { Treatment } \\
\text { Mean }\end{array}$ & $6.69^{B} \pm 0.29$ & $6.65^{\mathrm{B}} \pm 0.29$ & $5.75^{\mathrm{AB}} \pm 0.31$ & $4.85^{A} \pm 0.30$ & \\
\hline \multicolumn{6}{|l|}{ Significance } \\
\hline Treatment & $0.00 * *$ & & & & \\
\hline Duration & $0.03^{*}$ & & & & \\
\hline $\begin{array}{l}\text { Treatment } \times \\
\text { Duration }\end{array}$ & $0.00 * \star$ & & & & \\
\hline
\end{tabular}

\section{Quantitative and qualitative aspects of quail spermatozoa in response to BPA toxicity}


Data relating to influence of BPA on semen volume was presented in Table 6. Exposure to BPA resulted in lowered $(P<0.01)$ semen volume at low and high doses over a period of time. Quails exposed to high dose BPA for 10 wk period yielded critically lower volumes $(P<0.01)$. The sperm viability were observed to be significantly less (76.75\%) in high dose BPA group compared to low dose (82.38), sham control (87.13) and control (86.50) groups (Table 7). Lower viable sperm counts in T4 were accompanied by higher percent of abnormal spermatozoa. In concurrence, sperm motility and concentration were also affected to a great extent $(P<0.01)$ in high dose groups. Bisphenol-A caused significant $(P<0.01)$ reduction in sperm motility and corroborates with the previous findings in other animal species ${ }^{17,44}$. Disturbances in sperm motility by BPA is either due to depletion of anti-oxidant resources or intracellular ATP exhaustion ${ }^{45}$ or blockage of voltage activated $\mathrm{Ca}^{2+}$ channels $^{46}$ or disturbances in CatSper channel ${ }^{47}$ or alteration of mitochondrial membrane potential ${ }^{17}$.

Table 6

Semen volume $(\mu \mathrm{L})$ at different time points in Japanese quails as influenced by BPA administration (Mean \pm S.E, $n=15$ )

\begin{tabular}{|c|c|c|c|c|c|}
\hline $\begin{array}{l}\text { Duration } \\
\text { (weeks) }\end{array}$ & $\begin{array}{l}\text { T1 (Buffer } \\
\text { Control) }\end{array}$ & $\begin{array}{l}\text { T2 (Sham } \\
\text { Control) }\end{array}$ & $\begin{array}{l}\text { T3 (Low dose } \\
250 \mu \mathrm{g} / \mathrm{bird} \text { ) }\end{array}$ & $\begin{array}{l}\text { T4 (High dose } \\
1000 \mu \mathrm{g} / \mathrm{bird} \text { ) }\end{array}$ & $\begin{array}{l}\text { Duration } \\
\text { mean }\end{array}$ \\
\hline 8 & $\begin{array}{l}7.75^{\text {de }} \pm \\
0.48\end{array}$ & $\begin{array}{l}7.50^{\text {de }} \pm \\
0.29\end{array}$ & $6.50^{\mathrm{bcd}} \pm 0.50$ & $6.50^{\mathrm{bcd}} \pm 0.65$ & $\begin{array}{l}7.06^{Y} \\
\pm .231\end{array}$ \\
\hline 9 & $\begin{array}{l}7.75^{\text {de }} \pm \\
0.25\end{array}$ & $\begin{array}{l}7.00^{\text {cd }} \pm \\
0.00\end{array}$ & $4.75^{a b c} \pm 0.25$ & $4.50^{\mathrm{ab}} \pm 0.29$ & $\begin{array}{l}6.00^{\mathrm{X}} \\
\pm .231\end{array}$ \\
\hline 10 & $9.75^{e} \pm 1.03$ & $\begin{array}{l}8.50^{\text {de }} \pm \\
0.50\end{array}$ & $4.25^{\mathrm{ab}} \pm 0.25$ & $4.00^{\mathrm{a}} \pm 0.00$ & $\begin{array}{l}6.63^{X Y} \\
\pm .231\end{array}$ \\
\hline $\begin{array}{l}\text { Treatment } \\
\text { mean }\end{array}$ & $8.42^{\mathrm{B}} \pm .267$ & $7.67^{\mathrm{B}} \pm .267$ & $5.17^{\mathrm{A}} \pm .267$ & $5.00^{\mathrm{A}} \pm .267$ & \\
\hline \multicolumn{6}{|l|}{ Significance } \\
\hline Treatment & $0.00^{\star \star}$ & & & & \\
\hline Duration & $0.09 *$ & & & & \\
\hline $\begin{array}{l}\text { Treatment } x \\
\text { Duration }\end{array}$ & $0.00 \star \star$ & & & & \\
\hline $\begin{array}{l}\text { abc Means be } \\
\text { within colum }\end{array}$ & $\begin{array}{l}\text { different s } \\
\text { nd }{ }^{A B C} \text { Mear }\end{array}$ & $\begin{array}{l}\text { script differs } \\
\text { earing differe }\end{array}$ & $\begin{array}{l}\text { gnificantly. XYZ } \\
\text { superscript wit }\end{array}$ & $\begin{array}{l}\text { bearing differe } \\
\text { ws differs signif }\end{array}$ & rscript \\
\hline
\end{tabular}


Table 7

Semen characteristics in Japanese quails as influenced by various levels of Bisphenol-A exposure (Mean \pm S.E.M., $n=15$ )

\begin{tabular}{|c|c|c|c|c|c|c|}
\hline Treatment groups & $\begin{array}{l}\text { Mass } \\
\text { motility } \\
\text { (\%) }\end{array}$ & $\begin{array}{l}\text { Concentration } \\
\text { (billion/ml) }\end{array}$ & $\begin{array}{l}\text { Livability } \\
\text { (\%) }\end{array}$ & $\begin{array}{l}\text { Abnormality } \\
\text { (\%) }\end{array}$ & MBRT (s) & $\mathrm{pH}$ \\
\hline T1 (Buffer Control) & $\begin{array}{l}80.00^{\mathrm{a}} \pm \\
1.54\end{array}$ & $2.31^{b} \pm 0.07$ & $\begin{array}{l}86.50^{\mathrm{b}} \pm \\
1.29\end{array}$ & $7.38^{\mathrm{a}} \pm 1.05$ & $\begin{array}{l}52.25^{\mathrm{a}} \pm \\
3.35\end{array}$ & $\begin{array}{l}7.26^{b} \pm \\
0.08\end{array}$ \\
\hline T2 (Sham Control) & $\begin{array}{l}77.86^{\mathrm{a}} \pm \\
1.84\end{array}$ & $2.30^{\mathrm{b}} \pm 0.09$ & $\begin{array}{l}87.13^{b} \pm \\
1.30\end{array}$ & $6.50^{\mathrm{a}} \pm 0.71$ & $\begin{array}{l}53.88^{a} \pm \\
3.17\end{array}$ & $\begin{array}{l}7.13^{\mathrm{ab}} \pm \\
0.82\end{array}$ \\
\hline T3 (Low dose BPA) & $\begin{array}{l}71.43^{b} \pm \\
2.10\end{array}$ & $1.86^{\mathrm{b}} \pm 0.15$ & $\begin{array}{l}82.38^{\mathrm{ab}} \pm \\
2.25\end{array}$ & $\begin{array}{l}12.63^{b} \pm \\
1.63\end{array}$ & $\begin{array}{l}103.50^{\mathrm{b}} \pm \\
16.58\end{array}$ & $\begin{array}{l}6.93^{\mathrm{a}} \pm \\
0.07\end{array}$ \\
\hline T4 (High dose BPA) & $\begin{array}{l}70.00^{\mathrm{b}} \pm \\
1.54\end{array}$ & $1.66^{\mathrm{a}} \pm 0.14$ & $\begin{array}{l}76.75^{\mathrm{a}} \pm \\
2.88\end{array}$ & $\begin{array}{l}15.13^{b} \pm \\
2.16\end{array}$ & $\begin{array}{l}121.90^{\mathrm{b}} \pm \\
22.04\end{array}$ & $\begin{array}{l}6.96^{\mathrm{a}} \pm \\
0.06\end{array}$ \\
\hline Significance & 0.004 & 0.001 & 0.004 & 0.001 & 0.002 & 0.03 \\
\hline
\end{tabular}

The current study witnessed lower sperm counts $(P<0.01)$ in BPA treated male quails $(T 3: 1.86$ billion/mL; T4:1.66 billion/mL). The observed mean time of MBRT of semen in quails exposed to BPA increased $(\mathrm{P}<$ 0.01 ) than their control counterparts. In T1 and T2 groups of Japanese quail, time taken to decolorize methylene blue was varied between 52.25 to $53.88 \mathrm{~s}$ as against T3 and T4 group which witnessed 103 and $121 \mathrm{~s}$ respectively. Our current finding of MBRT values (Table 7) in BPA treated quails holds a strong evidence of this altered metabolic activity in sperm. BPA causes inhibition of spermatogonial cell proliferation in sertoli cells ${ }^{48}$ and seminiferous tubules ${ }^{49}$. Further, the increased sperm damage supports the toxicity of BPA on germ cell ${ }^{50}$. It is predicted that, these events induced by BPA may be responsible for lowered live sperm count associated with increased sperm abnormality in this study (Table 7) and is well supported by the findings of Aikawa et al ${ }^{51}$.

\section{Exposure to BPA did not influence seminal enzymes except ALP}

Among various seminal enzymes investigated (Table 8), only Alkaline phosphatase (KA units/ml) has showed a reduction $(P<0.01)$ in low $(1.13)$ and high dose $(0.93)$ BPA in comparison to control $(3.23)$ and sham control (4.00) groups. However, the present study witnessed no alteration with respect to ACP, AST and LDH enzymes. Alkaline phosphatase is a cell surface zinc metallo-enzyme believed to be involved in epithelial cell proliferation in sperm storage tubules in poultry ${ }^{52}$ by catalyzing the disassociation of phosphate groups from target substrates ${ }^{53}$. Mammalian studies indicated a tendency of correlation between ALP and fertility ${ }^{54}$. As far as LDH is concerned, a sharp drop was observed in seminal plasma in 
high dose treated group which could be well correlated with the reduced motility. As the LDH catalyzes the conversion of lactate to pyruvate and later deals with the energetics of sperm cells, its leakage might have critically disturbed the sperm motility and function ${ }^{55}$.

Table 8

Table 8. Effect of Bisphenol-A on enzymes in seminal plasma of male Japanese quail (Mean \pm S.E.M., $n=15$ )

\begin{tabular}{|lllll|}
\hline Treatment groups & ACP & ALP & LDH & AST \\
\hline T1 (Buffer Control) & $85.49 \pm 8.32$ & $3.23^{\mathrm{b}} \pm 0.43$ & $33.57 \pm 3.01$ & $2726 \pm 351$ \\
\hline T2 (Sham Control) & $77.28 \pm 824$ & $4.00^{\mathrm{b}} \pm 0.29$ & $35.42 \pm 2.53$ & $2970 \pm 352$ \\
\hline T3 (Low dose BPA) & $83.75 \pm 2.26$ & $1.13^{\mathrm{a}} \pm 0.31$ & $35.44 \pm 0.82$ & $2623 \pm 237$ \\
\hline T4 (High dose BPA) & $81.86 \pm 9.60$ & $0.87^{\mathrm{a}} \pm 0.15$ & $32.53 \pm 2.06$ & $3658 \pm 356$ \\
\hline Significance & 0.000 & & \\
\hline abc Means bearing different superscript within columns differs significantly \\
ACP: Acid phosphatase in KA units/mL; ALP: Alkaline phosphatase in KA units/mL. \\
LDH: Lactate dehydrogenase in IU/mL; AST: Aspartate aminotransferase in IU/MI \\
\hline
\end{tabular}

\section{BPA modulates serum testosterone concentrations in dose dependent manner}

Overall mean testosterone concentrations obtained after in vivo exposure in quails to varied levels of BPA were depicted in Fig. 1.Dose dependent response of BPA was noticed with modulating testosterone concentrations $(\mathrm{ng} / \mathrm{mL})$ in which T4 (2.21) has highest followed by T3 (2.99), T2 (3.99) and T1 (4.61) groups with a tendency of correlation $\left(r^{2}=0.37\right)$ with respect to dose level. BPA is good competitor to dihydroxy testosterone for androgen receptor mediated gene expression ${ }^{37}$ and reduces testosterone synthesis. Studies in rodents witnessed depressive effects of BPA on modulating concentrations of testosterone ${ }^{56,57}$. Leydig cells of testes and hypothalamus-pituitary axis are the probable routes through which BPA exerts its inhibitory effect on testicular function ${ }^{58,59}$. Findings of increased testosterone concentrations in response to BPA in chicken ${ }^{18}$ gains the possibility for the existence of species difference in terms of physiological behaviour and extent of metabolic activity to BPA. Even though, the present study did not measure the leutinizing hormone concentration, it is assumed that its low level might have reduced the testosterone synthesis ${ }^{60}$

\section{Higher but not lower doses compromised fertility and hatchability traits in quails}


Percent fertility, hatchability on TES and FES of quails as influenced by BPA toxicity were presented in Fig. 2. The fertility percentage in control, vehicle control, low dose and high dose BPA were 73.66, 67.96, 68.18 and 43.53 respectively. One of the noteworthy findings of this study is a progressive change in dose dependent form with high tendency of correlation is observed with respect to fertility $\left(r^{2}=0.88\right)$ that hatchability on TES $\left(r^{2}=0.88\right)$. Evidences indicating compromising actions of BPA on fertility are scarce. However, it is advocated that, exposure of mouse spermatozoa to $100 \mu \mathrm{m}$ concentration critically compromised in vitro fertilization rates ${ }^{48}$. Fertility is the obvious reflection of sperm motility, therefore deteriorated sperm quality characterized by higher number of dead and abnormal sperm counts in BPA treated groups explains the depression in fertility rates in this study. Reduction in testosterone and cloacal gland size clearly confirms the anti-androgenic actions of BPA ${ }^{61}$ which in turn affects the fertility and hatchability in quails. Hatchability results (Fig. 2) on adverse effects of BPA on total egg set basis warrants further investigation. Hatchability based on FES did not vary in response to BPA toxicity and hatchability on TES $\left(r^{2}=0.82\right)$. Interestingly, DES, an endocrine disruptor exposure also compromised hatchability of quail chicks ${ }^{54}$. Based on results of the current study, we confirm the compromising actions of BPA on reproductive success in Japanese quails at environmentally relevant concentrations under in vivo exposure module. It is likely that BPA mediated action is via distortions in sperm production and subsequently the fertility. The oscillating changes in foam frequency and cloacal gland size also indicate its higher sensitivity to BPA toxicity. We suggest progressive studies integrating genomic and proteomic analysis to elucidate the underlying mechanisms responsible for alteration of physiological and reproductive activities in quails.

\section{Materials And Methods}

All experimental protocols employed in this study were in accordance with the rules and guidelines framed and communicated by Committee for the Purpose of Control and Supervision of Experiments on Animals (CPCSEA), a statutory committee, which is established under Chap. 4, Sect. 15(1) of the Prevention of Cruelty to Animals Act 1960, India and approved by the Institute Animal Ethics Committee of the ICARCentral Avian Research Institute (452/01/ab/CPCSEA). The experimental procedures carried out in the study are in compliance with the ARRIVE guidelines.

\section{Experimental animals}

Male and female Japanese quails of CARI-Uttam variety was utilized as experimental subjects. Quails were sex differentiated by cloacal gland method and phenotypic thoracic feather pattern done at 8 wk of age. All the birds were maintained in individual cages $\left(4^{\prime} \times 2.5^{\prime} \times 1.5^{\prime}\right)$ with a space allowance of 175 sq.cm/bird, $16 \mathrm{~h}$ photoperiod, feed and water ad libitum. Sixty healthy adult quails were randomly allocated into four experimental treatment groups as control (T1), sham control (T2), low dose BPA (T3), and high dose BPA (T4) for a period of three wk i.e., 8-10 wk of age. All the male and female quails were 
fed with iso-nitrogenous and iso-caloric diets of laying quail ration formulated according to Bureau of Indian Standards, 1997 at institute feed processing unit. The ingredient composition, nutrient composition and protein fractions of the quail ration used in the experiment were presented in Table 9.

Table 9

Ingredient and nutrient composition of quail breeder diets used in the study

\section{Ingredient composition}

Ingredients (kg/100 kg) Starter (\%)

Maize

55

35

3.30

4

Fish meal

Lime stone

Di calcium phosphate

Salt

DL-Methionine

Trace mineral premix ${ }^{1}$

Vitamin premix ${ }^{2}$

Vitamin B complex

Choline chloride

Toxin binder

Total

Soybean meal

De-oiled rice bran

4

0.75

1.40

0.15

0.15

0.06

0.10

0.15

0.02

0.03

0.05

\section{Ingredient composition}

${ }^{1}$ Trace mineral premix (mg/kg diet): Mg- 300, Mn- 65, I- 1.2, Fe- 80, Zn- 40 and Cu-7.5. ${ }^{2}$ Vitamin premix (mg/kg diet)-Choline chloride- 500; Niacin: 12; Pyridoxine hydrochloride- 1.6; Vitamin K-1 mg, Vitamin $\mathrm{E}-10,{ }^{3} \mathrm{ME}$ : Metabolic energy, Calculated.

\section{Preparation and administration of Bisphenol-A}

Required BPA (>99\% Sigma Aldrich, USA) stock solutions were prepared by dissolving in Dimethyl sulfoxide (DMSO) (Sigma Aldrich) to a final volume of $0.25 \mathrm{~mL}$ per bird. In order to assess the BPA effect on male reproductive success, male quails were administered with BPA aqueous solution in form of oral gavage as $1 \mathrm{mg}$ and $5 \mathrm{mg}$ per $\mathrm{kg}$ BW to low and high dose treatment groups respectively. Sham control group with DMSO alone is maintained to nullify its interference in the experiment. Treatment groups T1, 
T2, T3 and T4 were administered with saline buffer alone, DMSO alone, BPA (mg/kg BW/d) 1 and 5 respectively for the duration of $3 \mathrm{wk}$. Oral gavage was administered to the birds with a tuberculin syringe during 08:00-9:00 daily prior to feeding.

\section{Body weight, testicular weights cloacal gland index and foam frequency measurements}

Body weight was recorded on weekly basis by weighing individual birds. Cloacal gland index (CGI) was measured as described previously ${ }^{26}$. Briefly, the dorso ventral and lateral aspects of cloacal gland were measured using Vernier calipers. The product of height (dorso-ventral aspect) and width (lateral aspect) of cloaca in $\mathrm{mm}^{2}$ was used as an index for measuring area of cloaca gland. The frequency of foam discharged from each bird was recorded between 0900 to $1500 \mathrm{~h}$ of the day during the course of treatment. Foam observations were recorded starting from 2nd wk of experiment i.e., 9 wk at 1, 3, 5, 7, 9, 11,13 and $15 \mathrm{~d}$. At the end of experiment, gross and normalized testicular weights were obtained by sacrificing six males from each treatment group.

\section{Collection, quantitative and qualitative analysis of quail spermatozoa}

All the semen analysis was done from the semen samples collected at the end of each wk during experiment i.e., 8, 9 and 10 wk. Neat semen was collected from each quail by gentle and frequent abdominal massages to avoid the contamination from frothy meringue like foam produced by cloacal gland. Foam contents were removed from cloacal gland prior to neat semen collection. The fresh semen, ejaculated from each bird, was measured by using graduated glass pipette of $0.1 \mathrm{~mL}$ and $0.001 \mathrm{~mL}$ accuracy. After recording the volume, semen samples from each group were mixed for further analysis. Qualitative estimates like per cent mass motility, livability, sperm concentration, and methylene blue reduction test (MBRT) were analyzed as described previously ${ }^{43}$. The neat semen $\mathrm{pH}$ was determined by pH-meter, (320213, Cyberscan. 2100) fitted with a microelectrode.

\section{Enzymatic estimation}

For measurement of enzymes in semen, semen samples that were collected during the experimental period were subjected to centrifugation at $4500 \mathrm{rpm}$ at $15 \mathrm{~min} / 4^{\circ} \mathrm{C}$ and separated seminal plasma samples were collected in a new tube and stored at $-80^{\circ} \mathrm{C}$ till further analysis. Metabolically important seminal enzymes viz. acid phosphatase (ACP), alkaline phosphatase (ALP), aspartate aminotransferase (AST) and lactate dehydrogenase (LDH) in seminal plasma were estimated by using standard commercial kits (Span Diagnostics, Gujarat, India) as per manufacturer's instructions. Test samples were 
accompanied by standard, negative and blank controls in all enzymatic tests. Absorbance readings for ACP, ALP, AST an LDH were recorded at 510, 505 and $340 \mathrm{~nm}$ respectively.

\section{Blood sampling and hormonal analysis}

For hormone measurement, whole blood samples were collected from jugular veins of quails and were subjected to centrifugation at 4,500 rpm/15 min. separated serum samples were transferred to new tubes and stored at $-80^{\circ} \mathrm{C}$ until analysis. Serum testosterone concentrations were estimated on weekly basis using solid phase enzyme-linked immunosorbent assay (ELISA) kit from Demeditec Diagnostics, Germany (DE1559) as per the manufacturer's instructions at $450 \pm 10 \mathrm{~nm}$ wavelength in a microplate reader (Spectramax190, Molecular Devices, USA). Briefly, test samples were added to antibody coated plates and conjugate was added to each well with an incubation of $37^{\circ} \mathrm{C}$ for $1 \mathrm{hr}$ and detailed washing. Plates were washed again after the addition of TMB substrate and the entire reaction was halted with the addition of stop solution. ELISA data was analyzed by plotting the mean absorbance values on the enclosed logit-log paper. Sample values were interpolated as percentage on the standard curve to obtain corresponding values final mean concentration in $\mathrm{ng} / \mathrm{mL}$. Inter and intra- assay coefficients of variation were found to be within 10 and 15 percent respectively.

\section{Fertility and hatchability studies}

For determination of fertility, paired mating was employed by assigning female of same hatch to Bisphenol-A treated males in 1:1 ratio for a period of $2 \mathrm{wk}$ and fertile eggs were collected for incubation. Percent fertility was determined by candling on 18th $d$ of incubation. Hatchability on total egg set (TES) and fertile egg set (FES) basis was recorded in percentage as per the standard formulae. Unhatched eggs were subjected to break open studies to ascertain the quail embryonic mortality pattern.

\section{Statistical analysis}

Percent values (Relative weight of testes, percent change in cloacal gland index, sperm motility, liveability, abnormality, fertility, hatchability on TES and FES) were subjected to arc sin transformation prior to analysis. All the generated experimental data were initially subjected to linear regression analysis (Graph pad prism version 7, San Diego, USA) to assess the significance of relationship between the experimental doses of BPA used in the study and various study parameters. Significance of differences among treatment means was calculated with tukey's post hoc test.

One way analysis of variance (ANOVA) was employed for rest of the observations (Relative testes weight, $\mathrm{pH}, \mathrm{MBRT}$, concentration, motility, liveability, abnormality, fertility and hatchability on TES, FES) to assess the significant differences among groups. While for those observations involved different time points viz. body weight, semen volume, serum testosterone, foam frequency and percent change in cloacal gland size; General linear model was adopted with treatment and duration as fixed effects. Statistical analysis 
was performed in SPSS version 20 (SPSS IBM, New York, U.S.A) and values were expressed as Means \pm SE. Values were considered at probability of 5 and $1 \%$ level as significant and highly significant respectively.

\section{Declarations}

\section{OPEN DATA AVAILABILITY STATEMENT}

Data, associated metadata, and calculation tools are available on request from the authors (Gautham.Kolluri@icar.gov.in)

\section{AUTHOR CONTRIBUTIONS STATEMENT}

S.S.P executed in vivo experimental trials, lab analysis and collected the data. J.M., R.P.S. conceived the idea and supervised the experiment. G.K. executed lab analysis, statistical analysis of data and drafted the manuscript. RPS Singh formulated the experimental substance doses. J.S.T. provided editorial and technical assistance. All the listed authors have read the manuscript and agreed to all of the contents.

\section{COMPETING INTERESTS}

The author(s) declare no competing interests.

\section{ACKNOWLEDGEMENT}

Authors extend their sincere thanks to Director, Central Avian Research Institute of Indian Council of Agricultural Research for providing us with all the necessary facilities and support. Authors are thankful to Dr. Gopi for providing assistance in statistical analysis of data. The work was carried out under research project Ref. No. P-101/2010/1-AV/L50/6400/6100, a regular institute grant. The manuscript was approved by Prioritization, Monitoring and Evaluation Cell vide no. CARI/PME/Pub-GK/63/RK-1/2 dated May 8, 2020.

\section{DISCLAIMER}

All authors declare that there exist no commercial or financial relationships that could, in any way, lead to a potential conflict of interest.

\section{ANIMAL WELFARE STATEMENT}


The authors confirm that the ethical policies of the journal, as noted on the journal's author guidelines page, have been adhered to and the appropriate ethical review committee approval has been received. The authors confirm the rules and guidelines framed and communicated by Committee for the Purpose of Control and Supervision of Experiments on Animals (CPCSEA), a statutory committee, which is established under Chapter 4, Section 15(1) of the Prevention of Cruelty to Animals Act 1960, India and approved by the Institute Animal Ethics Committee of the ICAR-Central Avian Research Institute (452/01/ab/CPCSEA). The experimental procedures carried out in the study are in compliance with the ARRIVE guidelines.

\section{References}

1. Rochester, J.R. Bisphenol A and human health: A review of the literature. Toxicol. 42, 132-155 (2013).

2. NIEHS (National Institute of Environmental Health Sciences). BisphenolA. https://www.niehs.nih.gov/health/topics/agents/sya-bpa/(2016).

3. Richter, C.A. et al.In vivo effects of bisphenol A in laboratory rodent studies. Toxicol. 24, 199-224 (2007).

4. Bonefeld-Jorgensen, E.C., Long, M., Hofmeister, M.V. \& Vinggaard, AM. Endocrine disrupting potential of bisphenol A, bisphenol A dimethacrylate, 4-nnonylphenol, and 4-n-octylphenol in vitro: new data and a brief review. Health. Perspect.115 (Suppl. 1), 69-76 (2007).

5. Sohoni, P. \& Sumpter, J.P. Several environmental oestrogens are also antiandrogens. Endocrinol.158, 327-339 (1998).

6. Takahashi, O. \& Oishi, S. Testicular toxicity of dietary 2,2-bis(4hydroxyphenyl) propane (Bisphenol A) in F344 rats. Toxicol. 75, 42-51 (2001).

7. Wetherill, Y.B. et al. In vitromolecular mechanisms of bisphenol A action. Toxicol. 24(2), 178-198 (2007).

8. Rogers, J.A., Metz, L., \& Yong, V.W. Endocrine disrupting chemicals and immune responses: A focus on bisphenol-A and its potential mechanisms. Immunol.53, 421-430 (2013).

9. Khan, D., \& Ahmed, S.A. Epigenetic regulation of non-lymphoid cells by bisphenol a, a model endocrine disrupter: potential implications for immunoregulation. Endocrinol.6(91), 1-7 (2015).

10. Liao, S.L. et al. Prenatal exposure to bisphenol-A is associated with Toll-like receptor-induced cytokine suppression in neonates. Pediatr Res.79, 438-444 (2016).

11. Colborn, T., Vom Saal, F.S. \& Soto, A.M. Developmental effects of endocrine-disrupting chemicals in wildlife and humans. Health. Perspect.101, 378-384 (1993).

12. Harrison, P.T., Holmes, P. \& Humfrey, C.D. Reproductive health in humans and wildlife: are adverse trends associated with environmental chemical exposure? Total Environ.205, 97-106 (1997).

13. Crain, D.A. et al. An ecological assessment of bisphenol-A: evidence from comparative biology. Toxicol. 24, 225-239 (2007). 
14. Peretz, J. et al. Flaws JA. Bisphenol A and reproductive health: update of experimental and human evidence, 2007-2013. Health. Perspect.122(8), 775-786 (2014).

15. Berg, C., Halldin, K. \& Brunstrom, B. Effects of Bisphenol A and Tetrabromobisphenol on sex organ development in quail and chicken embryos. Toxicol. Chem.20, 2836-2840 (2001).

16. Furuya, M., Sasaki, F., Hassanin, A.M.A., Kuwahara, S. \& Tsukamoto, Y. Effects of bisphenol-A on the growth of comb and testes of male chicken. Canadian J. Vet. Res.67, 68-71 (2002).

17. Singh, R.P. et al. Bisphenol A reduces fertilizing ability and motility by compromising mitochondrial function of sperm. Toxicol. Chem.9999(9999): 1-6 (2015).

18. Singh, R.P. et al. Effects of bisphenol-A on male reproductive success in adult Kadaknath chicken. Environ. Saf. 128, 61-66 (2016).

19. Xiao, S., Diao, H., Smith, M.A., Song, X. \& Ye, X. Preimplantation exposure to Bisphenol A (BPA) affects embryo transport, preimplantation embryo development, and uterine receptivity in mice. Toxicol.32, 434-441 (2011).

20. Nieminen, P. et al. Bisphenol A affects endocrine physiology and biotransformation enzyme activities of the field vole (Microtus agrestis). Comp. Endocrinol.126, 183e189 (2002a).

21. Nieminen, P. et al. In vivo effects of bisphenol A on the polecat (Mustela putorius). Toxicol. Environ. Health A,65, 933e945 (2002b).

22. Ma, , Crump, D., Farmahin, R. \& Kennedy, S.W. Comparing the effects of tetrabromo bisphenol-A, bisphenol-A and their potential replacement alternatives, TBBPA-BIS (2,3-Dibromopropyl ether) and Bisphenol-S on cell viability and messenger ribonucleic acid expression in chicken embryonic hepatocytes. Environ. Toxicol. Chem. 34(2), 391-401 (2015).

23. Halldin, K., Bergm C., Bergman, A., Brandt, I. \& Brunström, B. Distribution of bisphenol A and tetrabromobisphenol $A$ in quail eggs, embryos and laying birds and studies on reproduction variables in adults following in ovo exposure. Toxicol. 75(10), 597-603 (2001).

24. Vandenberg, L.N., Hauser, R., Marcus, M., Olea, N. \& Welshons, W.V. Human exposure to bisphenol A (BPA). Toxicol.24, 139-177 (2007).

25. Blomqvist, A. et al. Defective Reproductive organ morphology and function in domestic rooster embryonically exposed to o,p'-DDT or Ethynylestradiol. Reprod. 74, 481-486 (2006).

26. Singh, R.P. et al. Norfloxacin drug induces reproductive toxicity and alters androgen receptor gene expression in testes and cloacal gland of male Japanese quail (Coturnix japonica). Toxicol. Chem. 32, 2134-2138 (2013).

27. Ottinger, M.A. et al. Consequences of endocrine disrupting chemicals on reproductive endocrine function in birds: Establishing reliable end points of exposure. Dom. Anim. Endocrinol.29, 411-419 (2005).

28. Panzica, G.C., Muraf, E., Pessatti, M. \& Viglietti, C. Early embryonic administration of xenoestrogens alters vasotocin system and male sexual behaviour of the Japanese quail. Anim. Endocrinol.29, 436445 (2005). 
29. EU RAR, (2003). European Union Risk Assessment Report http://ecb.jrc.it/DOCUMENTS/Existingchemicals/RISK_ASSESSMENT/REPORT/bisphenolareport325.pdf

30. Schwetz, B. \& Harris, M. Developmental toxicology: status of the field and contribution of the national toxicology program. Health. Perspect.100, 269 (1993).

31. WHO (World Health Organization) . Reproductive and developmental toxicity of bisphenol A in mammalian Species. WHO Press, Ottawa (2010).

32. CASRN 80-05-7. Bisphenol A. http://www.epa.gov/nces/ iris/iris_documents/documents/subst/0356 (1988).

33. Wisniewski, P. et al. Adult exposure to bisphenol A (BPA) in Wistar rats reduces sperm quality with disruption of the hypothalamic-pituitary-testicular axis. 329, 1-9 (2015).

34. Munir, B., Abdul, Q. \& Mohammad, T. Negative effects of bisphenol A on testicular functions in albino rats and their abolitions with Tribulus terristeris L..Brazilian J. Pharm. Sci. 53(3), e00104 (2017).

35. Samova, S., Patel, C. N., Doctor, H., Pandya, H. A. \& Verma, R. J. The effect of bisphenol A on testicular steroidogenesis and its amelioration by quercetin: an in vivoand in silico Toxicol. Res. 7(1), 22-31 (2017).

36. Vijaykumar, T., Singh, D., Vanage, G.R., Dhumal, R.V. \& Dighe, V.D. Bisphenol A-induced ultrastructural changes in the testes of common marmoset. Indian J. Med. Res.146(1), 126-137 (2017).

37. Chen, Z. et al.Long-term exposure to a 'safe' dose of bisphenol A reduced protein acetylation in adult rat testes. Rep. 7, 40337 (2017).

38. Rahman, M et al. Bisphenol-A Affects Male Fertility via Fertility-related Proteins in Spermatozoa. Rep.5, 9169 (2015).

39. Hudson, L.N., Isaac, N.J.B. \& Reuman, D.C. The relationship between body mass and field metabolic rate among individual birds and mammals. Anim. Ecol. 82, 1009-1020 (2013).

40. Klemm, R.D., Knight, C.E. \& Stein, S. Gross and microscopic morphology of the glandula proctodealis (foam gland) of Coturnix. Morphol.141, 171-184 (1975).

41. Mohan, J., Moudgal, R.P., Sastry, K.V.H. \& Tyagi, J.S. Effect of hemicastration and castration on foam production and its relationship with fertilizing ability in male Japanese quail. 58, 29-39 (2002).

42. Fujihara, N. Accessory reproductive fluids and organs in male domestic birds. World's Sci. J., 48, 3956 (1992).

43. Suthan, S.P., Mohan, J., Sharma, S.K., Kolluri, G. \& Tyagi, J.S. Effect of Diethylstilbestrol on cloacal gland, foam frequency and semen characteristics of male Japanese quail. Indian J. Poult. Sci.51(1), 70-74 (2016).

44. Montgomery, T.M., Brown, A.G., Gendelman, H.K., Ota, M. \& Clotfelter, E.D. Exposure to 17aethinylestradiol decreases motility and ATP in sperm of male fightingfish Betta splendens. Toxicol. 29(3), 243-252 (2014).

45. Hulak, M., Gazo, I., Shaliutina, A. \& Linhartova, P. In vitroeffects of BPA on the quality parameters, oxidative stress, DNA integrity and adenosine triphosphate content in sterlet (Acipenser ruthenus) spermatozoa. Biochem. Physiol. 158, 64-71 (2013). 
46. Deutschmann, A., Hans, M., Meyer, R., Häberlein, H. \& Swandulla, D. Bisphenol A inhibits voltageactivated $\mathrm{Ca}(2 \mathrm{p})$ channels in vitro: mechanisms and structural requirements. Pharmacol. 83(2), 501-511 (2013).

47. Wang, H. et al. Bisphenol A Impairs Mature Sperm Functions by a CatSper-Relevant Mechanism. Sci.152(1), 145-154 (2016).

48. Chimento, A., Sirianni, R., Casaburi, I. \& Pezzi, V. Role of estrogen receptors and g protein-coupled estrogen receptor in regulation of hypothalamus-pituitary testis axis and spermatogenesis. Endocrinol.5, 1 (2014).

49. Furuya, M., Adachi, K., Kuwahara, S., Ogawa, K. \& Tsukamoto, Y. Inhibition of male chick phenotypes and spermatogenesis by bisphenol-A. Life Sci. 78, 1767-1776 (2006).

50. Meeker, J.D. et al. Semen quality and sperm DNA damage in relation to urinary bisphenol A among men from an infertility clinic. Toxicol.30(4), 532-539 (2010).

51. Aikawa, H. et al. Relief effect of vitamin A on the decreased motility of sperm and the increased incidence of malformed sperm in mice exposed neonatally to bisphenol A. Cell Tis. Res.315, 119-124 (2004).

52. Khillare, G.S., Sastry, K.V.H., Singh, R.P., Agarwaal, R. \& Mohan, J. Acid and alkaline phosphatase enzyme activity in sperm storage tubules in Japanese quail. Indian J. Poult. Sci. 48(1), 128-130 (2013).

53. Price, P.A., Toroian, D. \& Chan, W.S. Tissue-nonspecific alkaline phosphatase is required for the calcification of collagen in serum: a possible mechanism for J. Biol. Chem. 284, 4594-4604 (2009).

54. Pesch, S., Bergmann, M. \& Bostedt, H. Determination of some enzymes and macro- and microelements in stallion seminal plasma and their correlations to semen quality. 66, 307-313 (2006).

55. Odet, F. et al. Expression of the gene for mouse lactate dehydrogenase c (Idhc) is required for male fertility. Reprod.79(1), 26-34 (2008).

56. Akingbemi, B.T. Sottas, C.M., Koulova, A.I., Klinefelter, G.R. \& Hardy, M.P. Inhibition of testicular steroidogenesis by the xenoestrogen bisphenol $A$ is associated with reduced pituitary luteinizing hormone secretion and decreased steroidogenic enzyme gene expression in rat Leydig cells. 145(2), 592-603 (2004).

57. Jin, P. et al. Low dose bisphenol A impairs spermatogenesis by suppressing reproductive hormone production and promoting germ cell apoptosis in adult rats. Biomed. Res. 27(2), 135-144 (2013).

58. Kawai, K. et al. Aggressive behaviour and serum testosterone concentration during the maturation process of male mice: the effects of fetal exposure to bisphenol A. Health. Perspect.111, 175-178 (2003).

59. Zang, Z., Ji, S., Xia, S. \& Huang, T. Effects of bisphenol A on testosterone levels and sexual behaviors of male mice. Sex. Med.6, 41-49 (2016).

60. Nakamura, D. et al., Bisphenol A may cause testosterone reduction by adversely affecting both testis and pituitary systems similar to estradiol. Let.194, 16-25 (2010). 
61. Lee, H.J., Chattopadhyay, S., Gong, E.Y., Ahn, R.S. \& Lee, K. Anti-androgenic effects of bisphenol A and nonylphenol on the function of androgen receptor. Sci.75(1), 40-46 (2003).

\section{Figures}

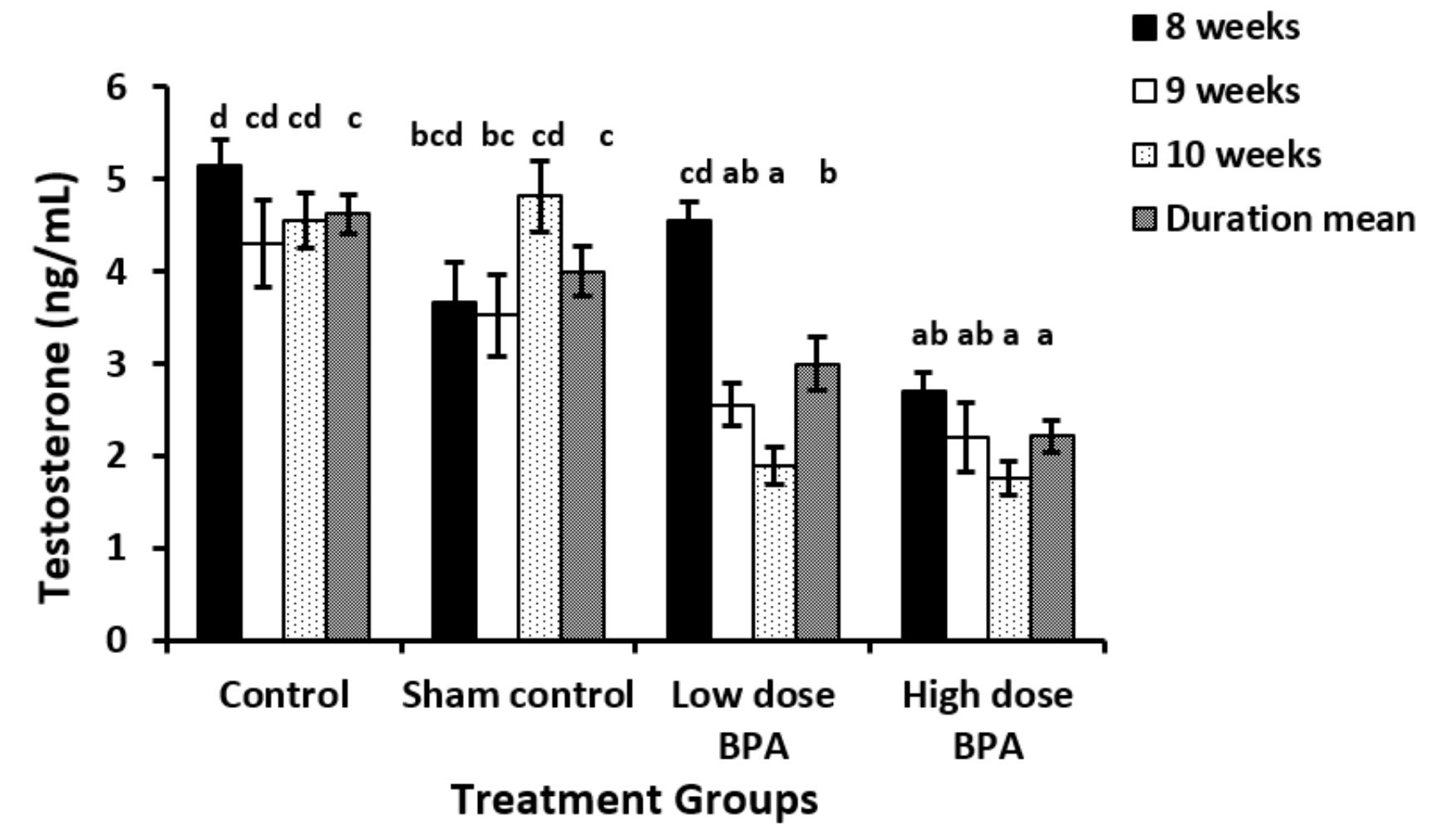

Figure 1

Means $\pm S E$ serum testosterone concentrations $(\mathrm{ng} / \mathrm{mL})$ in quails $(\mathrm{n}=15)$ in response to BPA administration (per day per kg BW basis). Column bars bearing different superscripts differs significantly. Effect of mean duration, mean treatment and their corresponding interaction is highly significant $(P<0.01)$. 


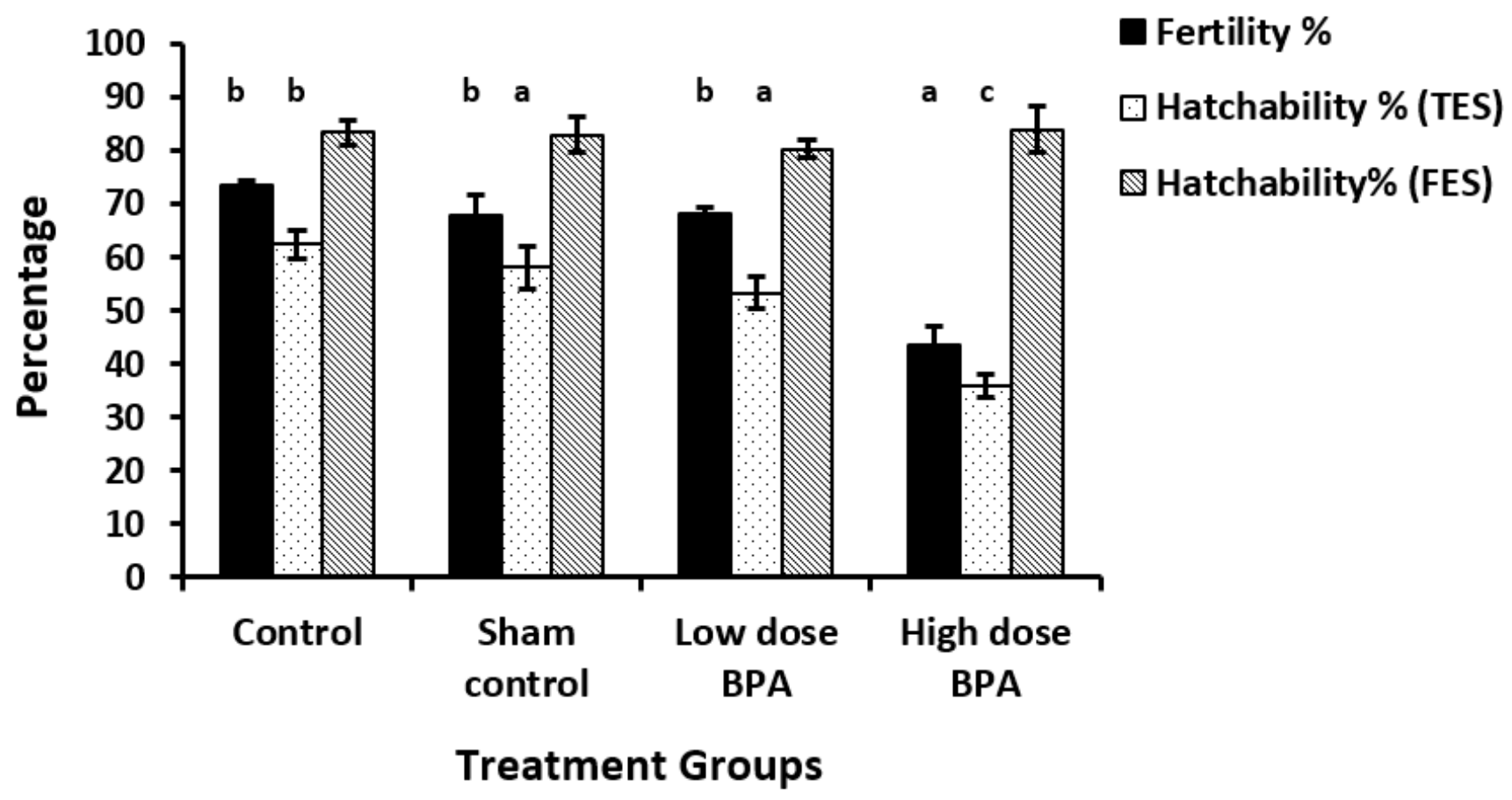

Figure 2

Means \pm SE percent fertility, hatchability on total egg set (TES) and fertile egg set (FES) basis in female quails inseminated from the semen of experimental male quails used in the study with an exposure to low $(1250 \mu \mathrm{g})$ and high $(5000 \mu \mathrm{g})$ doses of BPA (per day per kg BW basis). Column bars bearing different superscripts differs significantly. 